\title{
Cervical Spine Chondroma Compressing Spinal Cord: A Case Report and Literature Review
}

\author{
Yoon Hwan Byun ${ }^{1,2,3}$, Seil Sohn ${ }^{1,2,3}$, Sung-Hye Park ${ }^{5}$, Chun Kee Chung ${ }^{1,2,3,4}$ \\ ${ }^{I}$ Department of Neurosurgery, Seoul National University College of Medicine, Seoul, \\ ${ }^{2}$ Neuroscience Research Institute, Seoul National University Medical Research Center, Seoul, \\ ${ }^{3}$ Clinical Research Institute, Seoul National University Hospital, Seoul, \\ ${ }^{4}$ Department of Brain and Cognitive Sciences, Seoul National University College of Natural Sciences, Seoul, \\ ${ }^{5}$ Department of Pathology, Seoul National University Hospital, Seoul, Korea
}

Chondromas are benign tumor of cartilaginous tissue that is rarely found in spine. The authors document a rare case of a 72 year old male patient with a cervical spinal chondroma compressing the spinal cord. The patient had symptoms of motor and sensory deficits, dysphagia and dysarthria. C1 and C2 laminotomy was done and the spinal tumor was removed. The patient gradually recovered from his previous symptom after the surgery.

Key Words: Spine $\cdot$ Neoplasm $\cdot$ Chondroma $\cdot$ Cervical spinal cord

\section{INTRODUCTION}

Chondromas are benign tumor of the cartilaginous tissue ${ }^{7,19)}$. Spinal chondroma is very rare, especially in the cervical area ${ }^{5)}$ We report a rare case of a 72 year old male patient with cervical spine chondroma compressing spinal cord.

\section{CASE REPORT}

A 72 year old male patient visited the emergency room (ER) with progressive weakness and paresthesia in all extremities that were aggravated several days ago. On physical examination, the patient's motor power was decreased, showing grade III motor weakness on the right side and grade IV- on the left side. He also complained of dysarthria and dysphagia that began 12 hours before the visit to the ER. Cervical spine magnetic resonance (MR) image was taken at the ER and it showed a $3.4 \times 1.3 \mathrm{~cm}$ sized heterogeneously enhancing mass with

- Received: October 22, 2015 - Revised: November 23, 2015

- Accepted: November 23, 2015

Corresponding Author: Seil Sohn, MD, PhD

Department of Neurosurgery, Seoul National University College of

Medicine, 101 Daehak-ro, Jongno-gu, Seoul 03080, Korea

Tel: +82-2-2072-2350, Fax: +82-2-744-8459

E-mail: seilsohn@gmail.com

$\otimes$ This is an Open Access article distributed under the terms of the Creative Commons Attribution Non-Commercial License (http://creativecommons.org/ licenses/by-nc/3.0/) which permits unrestricted non-commercial use, distribution, and reproduction in any medium, provided the original work is properly cited. peripheral rim enhancement. The spinal tumor was based on dura and contained a cyst like portion. It was compressing the spinal cord and the exophytic cystic portion of the tumor was compressing the cervicomedullary junction (Fig. 1).

C1, C2 laminotomy was done using a conventional posterior approach. After the dura was opened, a greyish fibrous tumor
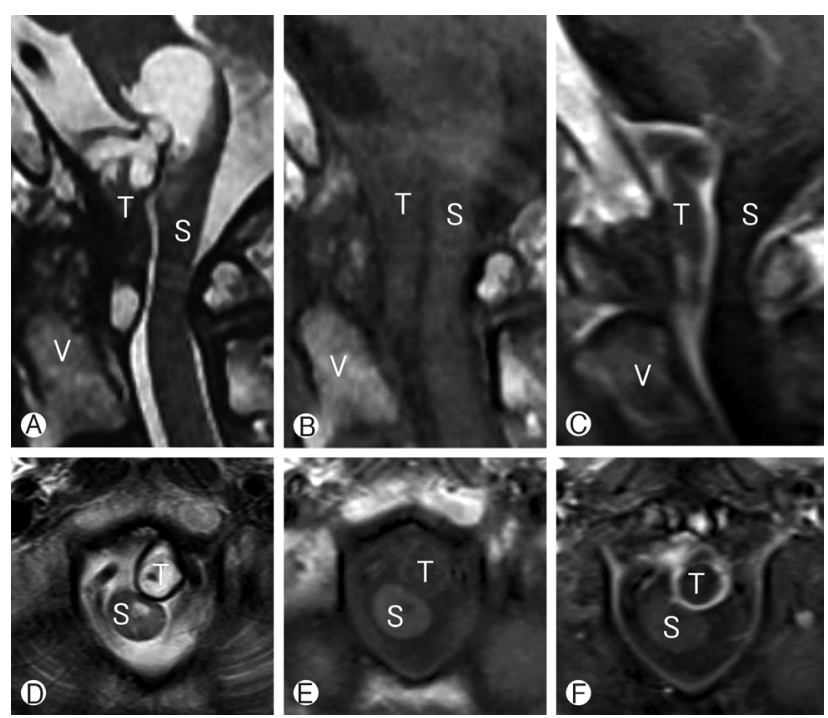

Fig. 1. Preoperative magnetic resonance (MR) image showed $3.4 \mathrm{X}$ $1.3 \mathrm{~cm}$ size heterogeneous mass (A, B, D, E). Tumor was based on dura and it contained cyst like portion. Tumor compressed spinal cord and had exophytic cystic portion compressing cervicomedullary junction $(C, F)$. Tumor had peripheral rim enhancement. $\mathrm{V}$, vertebral body; S, spinal cord; T, tumor. 


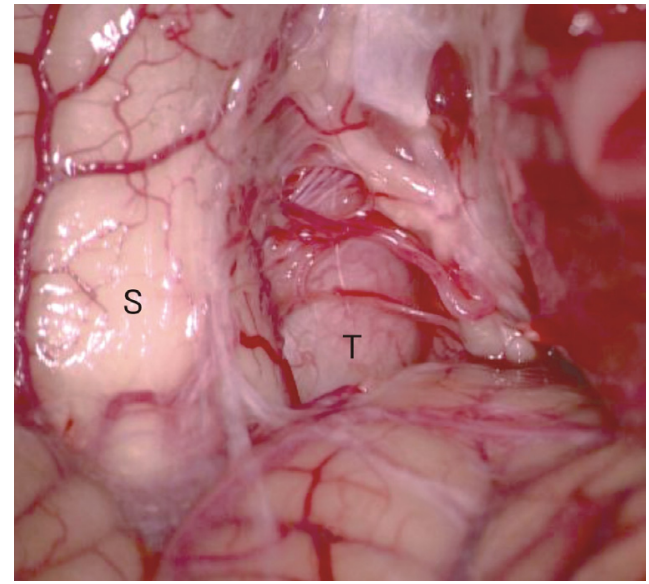

Fig. 2. A grayish fibrous tumor compressing the spinal cord was obsenved after dura was opened. S, spinal cord; T, tumor; C, cerebellum.
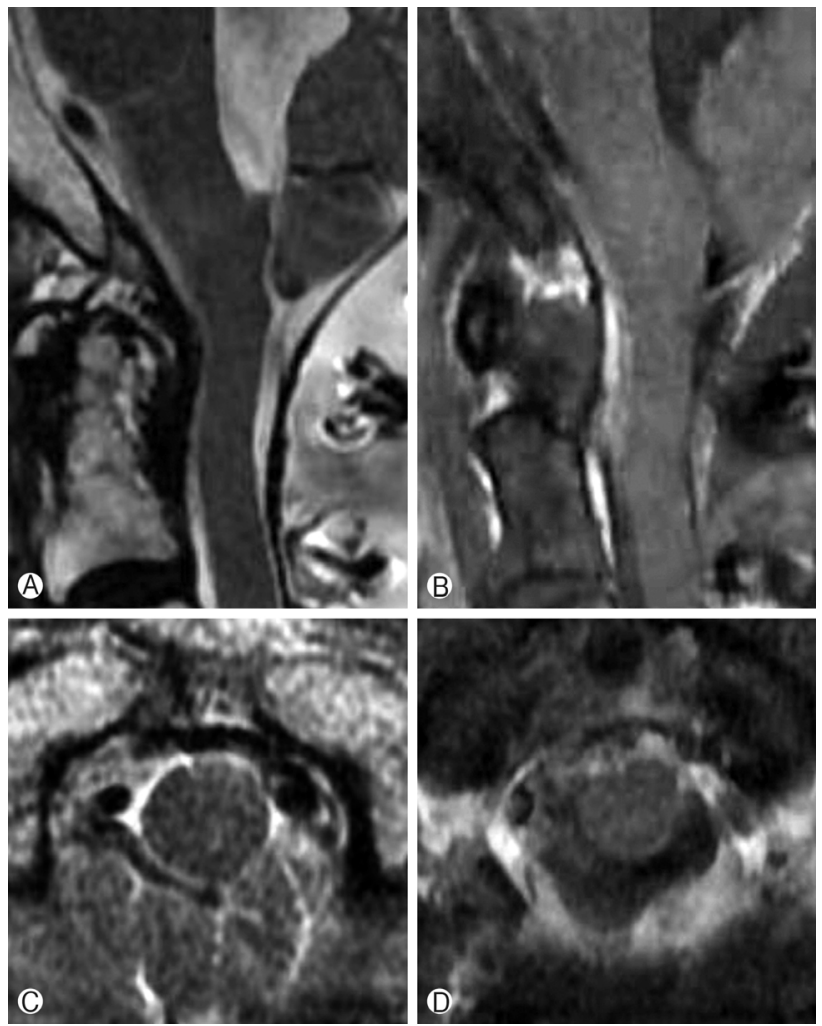

Fig. 3. Postoperative MR image showed markedly decreased tumor size. Spinal cord was decompressed.

compressing the spinal cord was seen outside the arachnoid membrane. The tumor was hard and was firmly attached to the ventral dura. There was no adhesion between the tumor and the spinal cord. The spinal cord was mildly deviated to the side due the ventrolaterally compressing tumor (Fig. 2). The tumor was intralesionally excised while saving the nerve roots.
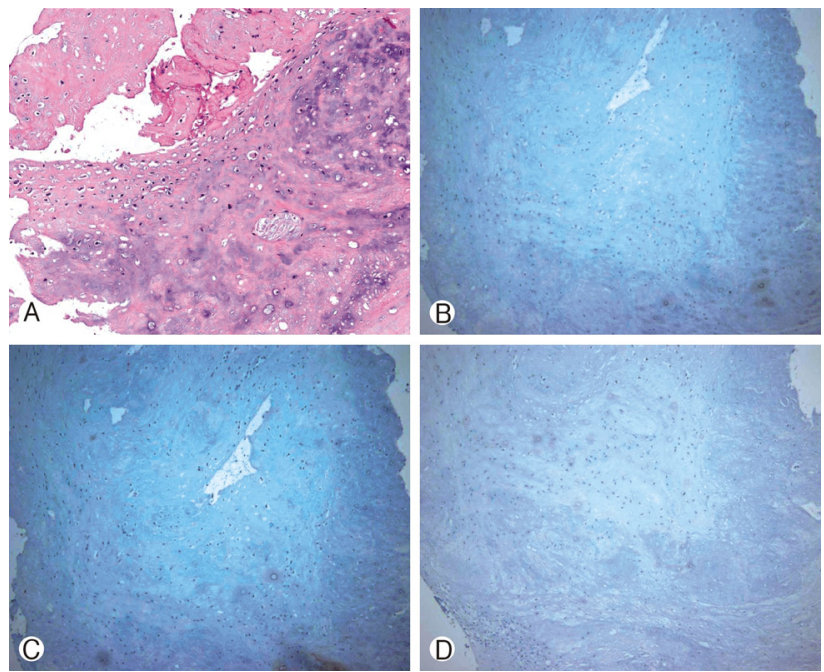

Fig. 4. (A) Hematoxylin-Eosin stained section of an excised chondroma. Immunohistochemical staining shows negative results for (B) Cytokeratin, (C) epithelial membrane antigen (EMA), and (D) S-100.

Postoperative MRI showed the tumor was removed well and the spinal cord was adequately decompressed (Fig. 3). This conventional posterior approach technique was similar in our previous report for ventral foramen magnum meningioma ${ }^{16}$.

Patient's motor weakness and paresthesia was gradually improved after the surgery. The patient was able to walk using a walker three months after the surgery. Sign of dysphagia also improved over time, and he was able to swallow food without aspiration one year after surgery. The final pathology report confirmed the spinal tumor as a chondroma. Immunohistochemistry staining for cytokeratin, epithelial membrane antigen (EMA), and S-100 protein stain were all negative (Fig. 4).

\section{DISCUSSION}

Chondromas are benign tumor of cartilaginous tissue that is found frequently in the tubular bone of hands ${ }^{13)}$. Chondroma within a vertebral body with neural compression has rarely been reported. It is postulated that spinal chondroma is derived from hyperplasia of immature spinal cartilage with migration outside the vertebral axis or from metaplasia of the connective tissue in contact with the spine or the anulusfibrosus ${ }^{8)}$.

There have only been 10 cases of previously reported cervical spine chondroma in adults ${ }^{1-3,6,8,9,13-15,18,19)}$ (Table 1). Eight among 10 cases occurred in young adults in their 20s-30s and all patients were male except for one case ${ }^{4)}$. Therefore, a cervical spine chondroma in a senile patient over 70 years of age, as in our case, is thought to be very rare. To our knowledge, our case is the first case of cervical spine chondroma 
Table 1. Published cases of cervical spine chondroma

\begin{tabular}{|c|c|c|c|c|c|c|c|c|}
\hline Authors & Year & Sex & Age & Country & $\begin{array}{l}\text { Cord } \\
\text { compres } \\
\text { sion }\end{array}$ & Presentation & Location & Outcome \\
\hline Maiuri et al. & 1980 & $M$ & 20 & Italy & Yes & $\begin{array}{l}\text { Progressive bilateral lower extremi- } \\
\text { ties weakness and spasticity }\end{array}$ & $\begin{array}{l}\text { C2-3, transverse process } \\
\text { and vertebral foramen }\end{array}$ & $\begin{array}{l}\text { Resolution of } \\
\text { symptoms }\end{array}$ \\
\hline Calderone et al. & 1982 & M & 20 & USA & No & Neck mass with tenderness & $\begin{array}{l}\mathrm{C} 2 \text {, arch and spinous } \\
\text { process }\end{array}$ & Not reported \\
\hline Willis & 1986 & M & 24 & USA & Yes & $\begin{array}{l}\text { Upper extremity weakness and } \\
\text { paresthesia }\end{array}$ & C3-5, vertebral body & $\begin{array}{l}\text { Resolution of } \\
\text { symptoms }\end{array}$ \\
\hline Lozes et al. & 1987 & $\mathrm{~F}$ & 76 & France & Yes & $\begin{array}{l}\text { Right cervicobrachial neuralgia, } \\
\text { right arm weakness }\end{array}$ & C4-5, vertebral foramen & $\begin{array}{l}\text { Resolution of } \\
\text { symptoms }\end{array}$ \\
\hline Barbar et al. & 1988 & M & 50 & USA & No & $\begin{array}{l}\text { Progressive numbness and pain of } \\
\text { left hand }\end{array}$ & $\begin{array}{l}\text { C4-5, lamina and } \\
\text { pedicles }\end{array}$ & $\begin{array}{l}\text { No progression of } \\
\text { preclinical symptoms }\end{array}$ \\
\hline Palaoglu et al. & 1988 & M & 30 & Turkey & Yes & $\begin{array}{l}\text { Hemiparessis of right side, } \\
\text { monoparesis of left arm }\end{array}$ & C5-6, vertebral body & $\begin{array}{l}\text { Recurrence after } 1 \\
\text { year, re-op. }\end{array}$ \\
\hline Antic et al. & 1992 & M & 28 & Yugoslavia & Yes & Spastic quadriparesis & C5-6, extradural & $\begin{array}{l}\text { Moderate paresis of } \\
\text { right arm }\end{array}$ \\
\hline Russo et al. & 2010 & M & 38 & Italy & Yes & $\begin{array}{l}\text { Neck pain and syndrome of spinal } \\
\text { cord compression }\end{array}$ & C5, right hemi lamina & $\begin{array}{l}\text { Resolution of } \\
\text { symptoms }\end{array}$ \\
\hline Wani et al. & 2011 & M & 25 & India & Yes & Quadriplegia & Atlas, posterior arch & $\begin{array}{l}\text { Significant improve- } \\
\text { ment of symptoms }\end{array}$ \\
\hline Raheja et al. & 2015 & M & 25 & India & Yes & $\begin{array}{l}\text { Spastic quadriparesis, sensory loss } \\
\text { below C4 dermatome }\end{array}$ & $\begin{array}{l}\text { C4-5, } \\
\text { intraduralextramedullary }\end{array}$ & Clinically stable \\
\hline Our Case & 2015 & M & 72 & $\begin{array}{l}\text { Republic } \\
\text { of Korea }\end{array}$ & Yes & $\begin{array}{l}\text { Progressive weakness and } \\
\text { paresthesia of four extremities }\end{array}$ & $\mathrm{Cl}-2$, vertebral foramen & $\begin{array}{l}\text { Resolution of } \\
\text { symptoms }\end{array}$ \\
\hline
\end{tabular}

with spinal cord compression in Republic of Korea, making it the $3^{\text {rd }}$ case report in Asia.

Chondroma is a slow growing tumor and neurologic symptoms and signs may develop gradually. Radiculopathy or myelopathy can result from direct neural compression ${ }^{11)}$. Most patients in previous studies had signs of spinal cord compression showing weakness and/or sensory deficit of extremities.

A plain X-ray may show a well circumscribed lytic lesion, with widened neural foramen if the tumor is intraforaminal ${ }^{2,13}$. A spine CT on bone setting may show a radiolucent and erosive lesion such as cartilage $\mathrm{e}^{10}$.

Spinal chondroma usually shows an intermediate signal intensity in T1 weighted MR image. The central part of mass may show a high signal on $\mathrm{T} 2$ weighted MR image, which is typically composed of hyaline cartilage with high water content ${ }^{12)}$. When we retrospectively reviewed our case, the cystic portion of the tumor which showed a high signal intensity on T2 weighted MR image, may have been the hyaline cartilaginous portion of the chondroma.

Histologically spinal chondroma is comprised of neoplastic chondrocytes dispersed within an abundant hyaline or myxoid background ${ }^{10)}$. Immunohistochemistry staining showed negative in cytokeratin, epithelial membrane (EMA), and S-100 antibody panels which excluded tumor of a neural crest origin or of a sarcomatous change.

Surgical excision of tumor is the recommended treatment for spinal chondroma although a case of spontaneous remission has been reported ${ }^{13)}$. In our case, we used a conventional posterior approach to resect the tumor instead of using a posterolateral or an anterolateral approach, which are more commonly used when resecting a ventrally located spinal tumor. A recent study has shown conventional posterior approach as a safe and an effective approach to resect tumor of ventral location $^{16)}$. This approach has a few advantages over other approaches, as being easier and more familiar to surgeons and showing faster postoperative recovery rate ${ }^{16}$.

Chemotherapy is ineffective for spinal chondroma, and radiation therapy is only considered for patients with unresectable tumors ${ }^{17}$. Recurrence rate is reported as less than $10 \%$ following complete resection of a chondroma ${ }^{11)}$.

\section{CONCLUSION}

Spinal chondroma is very rare, especially, in the cervical area. Cervical spine chondromas were mostly found in young male adults causing pain or motor/sensory deficit of extremities. We report a rare case of a cervical spine chondroma com- 
pressing the spinal cord in an old aged male patient. He showed paresthesia and weakness of all extremities, as well as, signs of dysphasia and dysarthria. Neurologic deficits gradually recovered after surgical resection.

\section{ACKNOWLEDGMENT}

This work was supported by the Seoul National University Hospital Research Fund (No. 0420143130).

\section{CONFLICT OF INTEREST DISCLOSURE}

The authors have no disclosure to report.

\section{REFERENCES}

1. Antić B, Roganović Z, Tadić R, Ilić S: Chondroma of the cervical spinal canal. Case report. J Neurosurg Sci 36:239-241, 1992

2. Baber WW, Numaguchi Y, Kenning JA, Harkin JC: Periosteal chondroma of the cervical spine: one more cause of neural fora men enlargement. Surg Neurol 29:149-152, 1988

3. Calderone A, Naimark A, Schiller AL: Case report 196: juxtacortical chondroma of C2. Skeletal Radiol 8:160-163, 1982

4. Cetinkal A, Güven G, Topuz A, Colak A, Demircan M, Haholu A: Lumbar spinal chondroma presenting with radiculopathy: cas ze report. Turk Neurosurg 18:397-399, 2008

5. Fahim DK, Johnson KK, Whitehead WE, Curry DJ, Luerssen TG, Jea A: Periosteal chondroma of the pediatric cervical spine. J Neurosurg Pediatr 3:151-156, 2009

6. Jeong D, Paeng S: Enchondroma of the cervical spine in young woman: A rare case report. Asian J Neurosurg 10:334-337, 2015
7. Kim $\mathrm{DH}$, Nam KH, Choi BK, Han I: Lumbar spinal chondroma presenting with acute sciatica. Korean J Spine 10:252-254, 2013

8. Lozes G, Fawaz A, Perper H, Devos P, Benoit P, Krivosic I, et al: Chondroma of the cervical spine. Case report. J Neurosurg 66: 128-130, 1987

9. Maiuri F, Corriero G, De Chiara A, Giamundo A, Benvenuti D, Gangemi M: Chondroma of the cervical spine: a case report. Acta Neurol (Napoli) 2:204-208, 1980

10. McLoughlin G, Sciubba D, Wolinsky J-P: Chondroma/Chondrosarcoma of the spine. Neurosurg Clin N Am 19:57-63, 2008

11. Morard M, De Tribolet N, Janzer RC: Chondromas of the spine: report of two cases and review of the literature. $\mathrm{Br} \mathrm{J}$ Neurosurg 7:551-556, 1993

12. Ogata T, Miyazaki T, Morino T, Nose M, Yamamoto H: A periosteal chondroma in the lumbar spinal canal. Case report. J Neurosurg Spine 7:454-458, 2007

13. Palaoglu S, Akkas O, Sav A: Chondroma of the cervical spine. Clin Neurol Neurosurg 90:253-255, 1988

14. Raheja A, Borkar S, Nalwa A, Suri V: Primary spinal extraosseous cervical chondroma in an adult. Neurol India 63:114116, 2015

15. Russo V, Platania N, Graziano F, Albanese V: Cervical spine chondroma arising from $\mathrm{C} 5$ right hemilamina: a rare cause of spinal cord compression. Case report and review of the literature. J Neurosurg Sci 54:113-117, 2010

16. Sohn S, Chung CK: Conventional Posterior Approach without Far Lateral Approach for Ventral Foramen Magnum Meningiomas. J Korean Neurosurg Soc 54:373-378, 2013

17. Somers J, Faber LP: Chondroma and chondrosarcoma. Semin Thorac Cardiovasc Surgery 11:270-277, 1999

18. Wani A, Zargar J, Ramzan A, Malik N, Lone I, Wani M: Isolated enchondroma of atlas. Turk Neurosurg 21:226-229, 2011

19. Willis BK, Heilbrun MP: Enchondroma of the cervical spine. Neurosurgery 19:437-440, 1986 